\title{
植生を考慮した千曲川の洪水流と河床変動の解析 FLOOD FLOWS AND RIVER-BED VARIATION ANALYSIS FOR THE CHIKUMA RIVER WITH VEGETATION
}

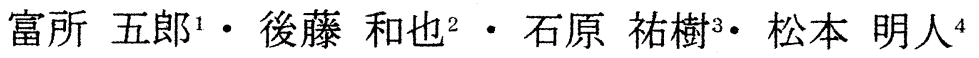 \\ Goro TOMIDOKORO, Kazuya GOTOH, Yuuki ISHIHARA and Akihito MATUMOTO

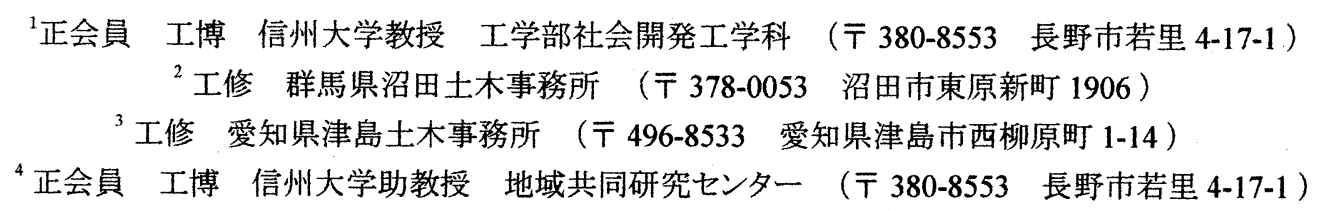

The flood flows and river-bed variation of the Chikuma river with vegetation zone on major bed were analyzed. In this study, flood flows were assumed to be two-dimensional in horizontal direction, and the Galerkin finite element method was applied to the basic equations for spatial directions and the two-step Lax-Wendoroff method was employed for time direction. The hydrauric resistances of plants on major bed were idealized to dispersive resistance on river bed in one case or were culculated according to the water depths and the plant shapes in the other case. The analytical zone was from confluence of the Sai and Chikuma river to Tategahana, $13.5 \mathrm{~km}$ length, about $1.0 \mathrm{~km}$ width. The flood water levels measured('83.9) and these numerical results showed good agreement.

Key Words : flood flows, river-bed variation, Chikuma river, vegetation

\section{1. はじめに}

河川環境を知る手がかりの一つに河川敷地内の樹 木, 草花の存在が挙げられる.これらは河川の生態系 の保持の他, 川を安らぎの場所にする大切な要素であ る. その一方で, 洪水の流れを妨げて治水の安全性を 損なう恐れもある. そこで, 河道内に樹木等の植生が 存在した場合の水の流れを把握し, 洪水の危険性を 知ることが必要となる. 研究対象となる千曲川は写真1に示すように高水敷にリンゴ, 桃等の果樹園が存在 する特徵的な河川である. そこで本研究では植生分布 を考慮した千曲川における洪水流の数値解析を行 い, 広範囲な植生と狭窄部の存在する実際の河川に 対する数值解析の可能性と, 植生の洪水流や河床変 動に及ぼす影響について検討している.

流れの数值解析手法としては, 流れを二次元と仮定 して, 空間変数に対してはGalerkin有限要素法を, 時 間変数に対してはtwo-step Lax-Wendroff法によって 離散化し解析を行う. 解析メッシュの作成には, 解析 精度を確保するために狭窄部や複雑な植生分布を考
慮して解適合格子法を用いている. 樹木の抵抗は, 底 面の抵抗に分散させるものとして, 各々の樹木のある 地目每に合成粗度係数を一定値とする方法と樹形を 考慮した水深の関数とする二方法を用いる. そして, 昭和58年9月('83.9)の既往最大洪水の洪水痕跡と最 大流量が流れる定常流とした数值解析の水位との比 較を行う。

また, 洪水時の河床変動は流れ解析に大きな影響 を与えるので, 河床材料の粗粒化も予測可能な簡便 な河床変動解析を試みる.

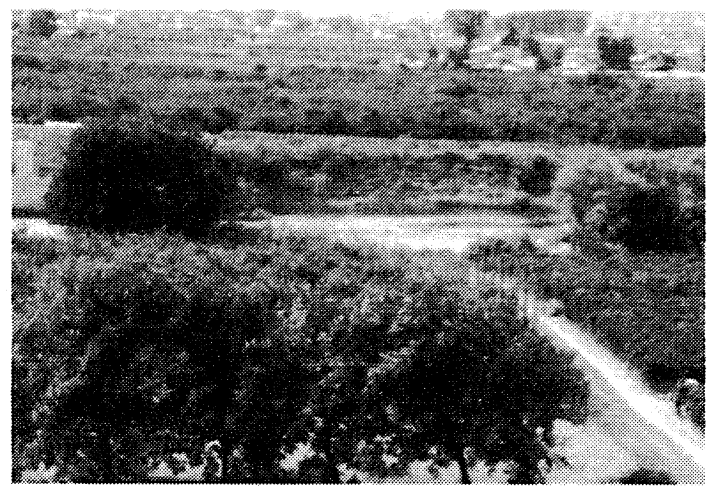

写真-1 千曲川の高水敷のりんご畑 


\section{2. 解析方法}

\section{(1)流れの解析}

開水路の流れの基礎方程式”はReynoldsの運動方 程式と連続式で与えられる.

$$
\begin{aligned}
& \frac{\partial u}{\partial t}+u \frac{\partial u}{\partial x}+v \frac{\partial u}{\partial y} \\
& =g I_{x}-g \frac{\partial \zeta}{\partial x}+\frac{\partial}{\partial x}\left(A_{h} \frac{\partial u}{\partial x}\right)+\frac{\partial}{\partial y}\left(A_{h} \frac{\partial u}{\partial y}\right)-\tau_{x} \\
& \frac{\partial v}{\partial t}+u \frac{\partial v}{\partial x}+v \frac{\partial v}{\partial y} \\
& =g I_{y}-g \frac{\partial \zeta}{\partial y}+\frac{\partial}{\partial x}\left(A_{h} \frac{\partial v}{\partial x}\right)+\frac{\partial}{\partial y}\left(A_{h} \frac{\partial v}{\partial y}\right)-\tau_{y} \\
& \quad \frac{\partial \zeta}{\partial t}+\frac{\partial}{\partial x}(u \cdot d)+\frac{\partial}{\partial y}(v \cdot d)=0 \\
& \tau_{x}=g n^{2} u \sqrt{\left(u^{2}+v^{2}\right)} / d^{4 / 3} \\
& \tau_{y}=g n^{2} v \sqrt{\left(u^{2}+v^{2}\right)} / d^{4 / 3}
\end{aligned}
$$

ここに，x軸は $x$ 方向の平均勾配 $I_{x}$ に平行に，y 軸は $y$ 方向の平均勾配 $I_{y}$ に平行に水面付近にとり, $z$ 軸は $x-y$ 平面に直角に鉛直上方を正としている. また, $u, v$ はそれぞれ鉛直平均流速の $x, y$ 成分, $t$ は時間, $g$ は重力加速度, $d$ は水梁, $n$ はマニングの粗度係数, $\zeta$ は水面上昇量, $A_{k}$ は水平渦動粘性係数, $\tau_{x}, \tau_{y}$ は $x, y$ 方向の底面せん断応力を $\rho d$ で除したもので あり, $\rho$ は水の密度である.

上式の空間変数に対してはGalerkin有限要素法を, 時間変数に対してはtwo-step Lax-Wendroff法を用い て離散化する.

水平渦動粘性係数は, $k-\varepsilon$ 乱流モデル等を用い る方法もあるが, ここでは簡単のため, Reynoldsの相似 仮定を用いてElderの定義源に従い, 次式で算定する.

$$
A_{h}=K n \sqrt{g\left(u^{2}+v^{2}\right)} / d^{5 / 6}
$$

ここに, $K$ は定数で, ここでは 6.0 とする.

\section{(2)河床変動解析}

本河床変動解析は, 河床面近くに砂䂺の移動によ り時間的に粒度分布が変化するが, 鉛直方向に粒度 分布の一定な交換層を考える. また, 空隙率 $(\boldsymbol{\lambda})$ の時 間的変化は小さいとして無視し, 各粒径範囲別に区分 された砂碑に対して次の二次元の連続式を適用する.

$$
\frac{\partial z_{i}}{\partial t}+\frac{1}{1-\lambda}\left(\frac{\partial i_{b} \cdot q_{B x i}}{\partial x}+\frac{\partial i_{b} \cdot q_{B j i}}{\partial y}\right)=0
$$

ここに，ibは交換層内のある粒径範囲の砂砂 $\left(d_{1}\right)$ が 占める割合, $z_{\mathrm{i}}=a \cdot i_{\mathrm{b}}$ はその砂䃇の交換層内で占める 高さ， $q_{B \mathrm{Bx}}, q_{B \mathrm{yi}}$ はそれぞれ $\mathrm{x}, \mathrm{y}$ 方向の $d_{\mathrm{i}}$ の流砂量, $a$ は交換層厚である.

本研究で提案する簡易な河床変動解析の目的は, 流れとの連動解析を最終目的にして, 洪水時の流れ
特性に大きな影響を与える低水路等の河床低下を予 測することにある.また, 解析は洪水ピーク時における 流量変化の小さい, 短時間を想定しており, 洪水減水 時のような砂碟の堆積も少ない. そこで以下では, 浮 遊砂を無視して, 簡便な次の Meyer-Peter·Müler の 式 ${ }^{3)}$ 混合砂碎に搪張した次式で流砂量を評価する.

$$
\begin{gathered}
q_{B s i}=8\left(\tau_{* e i}-\tau_{* c i}\right)^{3 / 2} \cdot \sqrt{s g d_{i}^{3}} \\
d_{i} / d_{m}>0.4: \tau_{* i}=\left(\frac{\log 19}{\log \left\{19\left(d_{i} / d_{m}\right)\right\}}\right)^{2}\left(\frac{d_{i}}{d_{m}}\right) \tau_{* c m} \\
d_{i} / d_{m} \leqq 0.4: \tau_{* c i}=0.85 \tau_{* c m} \\
\tau_{* e i}=\frac{u_{* e}^{2}}{s g d_{i}}, \quad u_{* e}=\left(\frac{n_{b}}{n}\right)^{3 / 4} \cdot u_{*}, n_{b}=0.0192 d_{m}{ }^{1 / 6} \\
u_{*}=\sqrt{\left(u^{2}+v^{2}\right)} /\left\{6.0+5.75 \log \left(h / 2.5 d_{m}\right)\right\}
\end{gathered}
$$

ここに，下添え字 $\mathrm{i}$ は $d_{\mathrm{i}}$ のそれらを表し，また $q_{B s i}$ は流

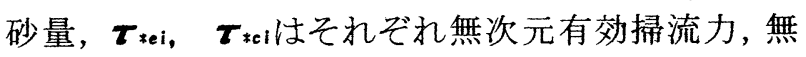
次元限界掃流力, $s$ は砂磻の水中比重, $d_{\mathrm{m}}$ は混合砂 磂の平均粒径, $u$ * 恬摩擦速度, $\boldsymbol{\tau} \times \mathrm{ra}$ は $d_{\mathrm{m}}$ の無次元限 界掃流力で岩垣の式 ${ }^{31} よ り$ 評価する.

これらの連続式の離散化は, 流れの解析と同様であ る. 実際の計算においては, 時間刻みdt毎に得られた $z_{\mathrm{i}}$ を全ての $d i$ について合計すると交換層厚となり,こ れより河床面が求められる. 更に, 得られた $a$ で $z_{i}$ を 割ることにより $i_{\mathrm{b}}$ が求められる. また, 空隙率は, 時間 刻み $d \mathrm{t}$ 間では一定としているが, 次の時間刻み $d \mathrm{t}$ では, 新たに求めた中央粒径の関数として計算した值 を用いる。

交換層厚はアーマーコートの厚さ程度として, 最大 粒径 $\left(d_{\max }\right)$ とする. 計算の進行により，aは $d_{\max }$ を越え たり, 下回ったりする.この過不足は, 交換層の下の層 で調整を行うが,この際にはこの層の粒径分布が必要 になる. 本研究では交換層下に層厚一定な層を設け, この調整に伴う層間の各粒径範囲の砂磁の調整量か ら,これらの層の層内平均 $i_{\mathrm{b}}$ を計算する.これらの層 では砂碟の移動がないことより鉛直変化を考慮し，i に直線分布を仮定する.この傾きは, 河床上昇時には 層下部の值を, 降下時には上部の値を前の計算ステ ップ值から内插して決める.これは, 層間の各粒径範 囲の砂碟の調整量誤差を小さくするためである.これ らの計算は, 氾濫計算の移動境界部のボリューム調整 と同様に行える.

本研究の初期条件では, 粒度分布を鉛直方向に一 定とするが，時間経過過程で同一点の河床が一方的 に上がるか, または下がる場合には, 交換層の下の層 で新たに計算される $i_{6}$ は全く使われなく, 計算精度に 影響を及ぼさない. そこで, 本解析では, この層数を 1 層として, 層厚を交換層厚の 2 倍としている.

尚, 本研究では文献 4)に従って, 流線方向の粒砂 量を求めている. 
粒径は, 文献 5)を参考に $0.1 \mathrm{~cm} \sim 1.0 \mathrm{~cm}$ を $0.1 \mathrm{~cm}$ 毎 の9区分, $1.0 \mathrm{~cm} \sim 4.0 \mathrm{~cm}$ を $0.5 \mathrm{~cm}$ 毎の 6 区分, $4.0 \mathrm{~cm} \sim 6.0 \mathrm{~cm}$ を $1.0 \mathrm{~cm}$ 毎の 2 区分, $6.0 \mathrm{~cm} \sim$ $12.0 \mathrm{~cm}$ を $2.0 \mathrm{~cm}$ 毎の 3 区分の合計 20 の粒径範囲に 細分する. 各粒径範囲の代表粒径は, その最大值と 最小值の積の平方根とする. 尚, この最大粒径を一様 粒径しした解析を行ったところ, 狭究部の最大流速部 以外では河床変動は見られなかった。

\section{3. 粗度係数決定の概念}

本研究では, 合成粗度係数を植生のある地目毎に 一定とする方法 (case-1) と樹形を考慮した水深の関数 とする方法 (case-2)を採用している. 後者は樹木の場 合, 水位により抵抗が著しく変化するため, 樹木を枝 下部と樹幹部に分け, 水深に対応した粗度係数を与 える必要性がある. そこで果樹と広葉樹に対し粗度係 数を水深の関数として次式で算出した. ${ }^{6)}$

幹部分のみ浸水する場合 $(h \leqq h o)$

$$
n=\left(n_{b}^{2}+\frac{a}{2 g} C_{D} h^{4 / 3}\right)^{1 / 2}
$$

樹幹部まで浸水する場合 $(h o<h \leqq H)$

$$
n=\left\{n_{b}{ }^{2}+\frac{a}{2 g} h^{1 / 3}\left(C_{D} D h_{0}+C_{u} a_{u}\right)^{1 / 2}\right.
$$

ここに, $h$ は水梁, $h_{0}$ は枝下高, $H$ は樹木高, $n_{b}$ は 底面のマニング粗度係数, $n$ は合成粗度係数, $C_{D}$ は 樹木の抗力係数, $C_{u}$ は樹幹部の抗力係数, $D$ は幹 径, $a$ は樹木の育成密度, $a_{u}$ は樹幹部の投影面積で ある。

また, 本研究で用いた果樹と広葉樹の解析モデル を図-1, 図-2にそれぞれ示す. 図は千曲川河川敷に 植樹されている果樹と広葉樹の平成 10 年の実測値を 模式化したもので, 桑は桑畑の面積が小さいので模式 化していない. また, 果樹と広葉樹の地目の樹木密度 $a$ は，それぞれ $1 / 36.0,1 / 30.0\left(\right.$ 本 $\left./ \mathrm{m}^{2}\right)$ である.

\section{4. 解析対象河道と計算条件}

\section{（1） 解析対象河道の概要}

本研究における計算対象河道は, 長野市東部の千

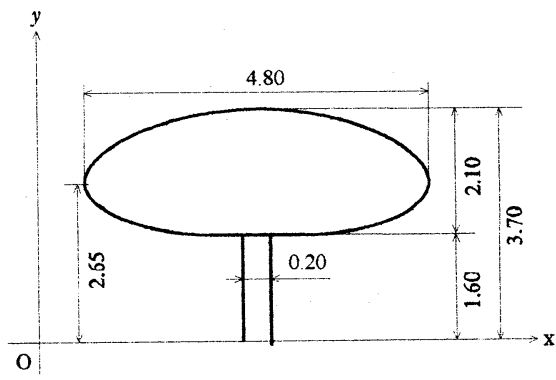

図-1 果樹の模式図 [単位：m]

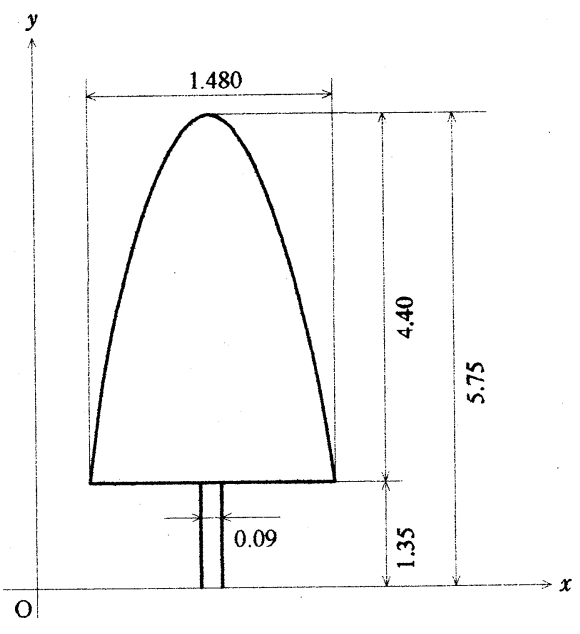

図-2 広葉樹の模式図[単位: $\mathrm{m}]$

曲川と犀川合流地点より下流 $500 \mathrm{~m}$ 地点から立ヶ花橋 地点までの総延長 $13.5 \mathrm{~km}$ の区間である. 川幅は $1 \mathrm{~km}$ 弱, 河川勾配は $1 / 1000$ 程であるが, 下流の狭窄部で はそれぞれ $200 \mathrm{~m}, 1 / 700$ 程に急変している. 川の横断 面は, 狭窄部以外では複断面形で, 高水敷は果樹園 等として利用され，ほぼ全体が植生に覆われている. 図-3に, 昭和 58 年当時の解析領域の果樹, 低水路, 砂地, 荒地, 畑, 広葉樹, 狭窄部, 桑畑の8種類の地 目分布を示す.

解析メッシュは，以下の手順に従って作成している. 1) $500 \mathrm{~m} ヒ ゚ ッ チ の$ 横断測量結果より, 節点数 275 点の初 期メッシュを作成する.

2)ブロック別修正デローニー三角分割法により，急縮 部を細かくした節点数 $2012 の$ 解析メッシュを作成する. 3)この解析メッシュによる流速の計算結果を用いて, 解 適合格子法" くした節点数 4000 点の二次解析メッシュを作成する.

最終的な解析メッシュは，2），3）を試行錯誤して作成 した解析メッシュで, 解の安定性に高いメッシュを用い ている(図-3). なお，3)で解適合格子法の代わりに，通 常の修正デローニー三角分割法を用いた場合には， 流速変化の激しい箇所の分割が不十分で,この解析 メッシュを用いた計算では，途中で解が発散したり，得 られても精度が悪いものであった。

\section{(2)流れの解析条件}

本研究では, 千曲川の昭和58年9月の最大流量 740 $0 \mathrm{~m}^{3} / \mathrm{s}$ の既往最大洪水の洪水痕跡を数值解析による 再現を試みるものであるが, 上流端での非定常計算の ためのデータがないことと, 洪水のピーク流量付近の 比較的フラットな状態が，解析領域を流れが通過する のに要する時間以上に継続していて, 流れは解析領 域で定常流に近いと考えて, 解析は最大流量が流れ る定常流としている. 流れの初期条件として, 流速は すべて零とし, 水位は上下流端でその洪水痕跡に, 中 


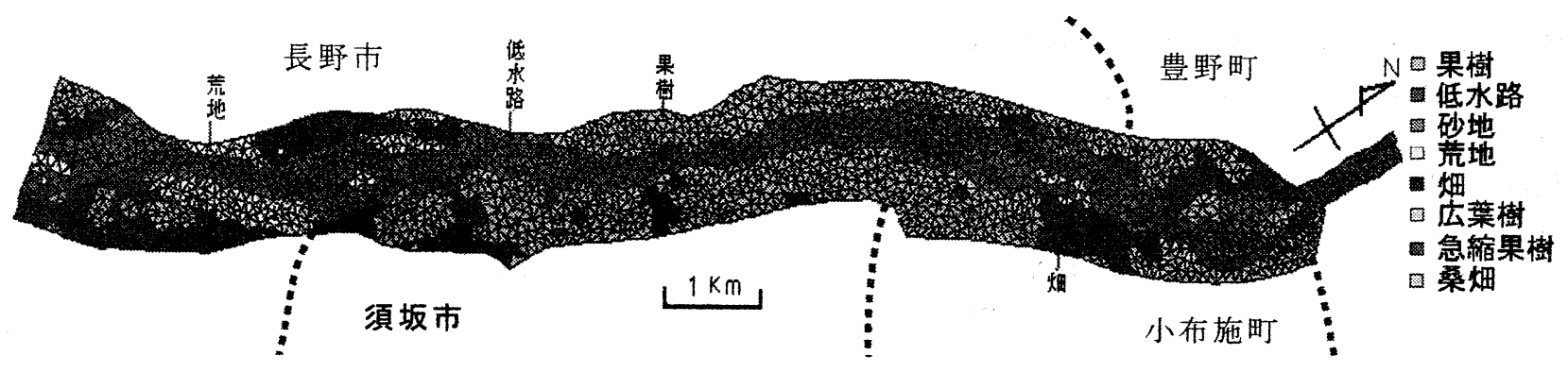

図-3 昭和58年当時の千曲川の地目分布図と解析メッシュ(右が下流方向)

間で直線補間した値としている.

上下流端の境界条件として, 水位は実際の洪水痕 跡線に拘束し, 流速は零加洪水時の最大流量と水 位をもとに境界付近の植生を考慮した流速に $\sin$ 曲線 により短時間で立ち上げ, その後一定值に固定してい る. また，両岸の流速はすべて零に拘束する.

\section{(3)河床変動の解析条件}

河床変動解析における流速と水媣の初期値は, 流 れ解析によって得られた流量ピーク時のデータを使用 している. その後は, 河床変動による水樑の変化に応 じて, 各節点での流量が維持されるように流速を変化 させている.これは, 本来なら時間ステップごとに河床 変動をを取り入れた流れの計算を繰り返すべきである が, 計算時間の都合と, 河床変動量が水深に比べて 小さいことから，上のような簡便法を用いている.

上流端の流砂量は, それを評価する上流のデータ がないため, 上下流端とも拘束せず，それぞれの境界 において流れに基づく掃流力を用いて境界内部で計 算された平衡流砂量としている.

解析においては, 平水時に形成され, 洪水増水期

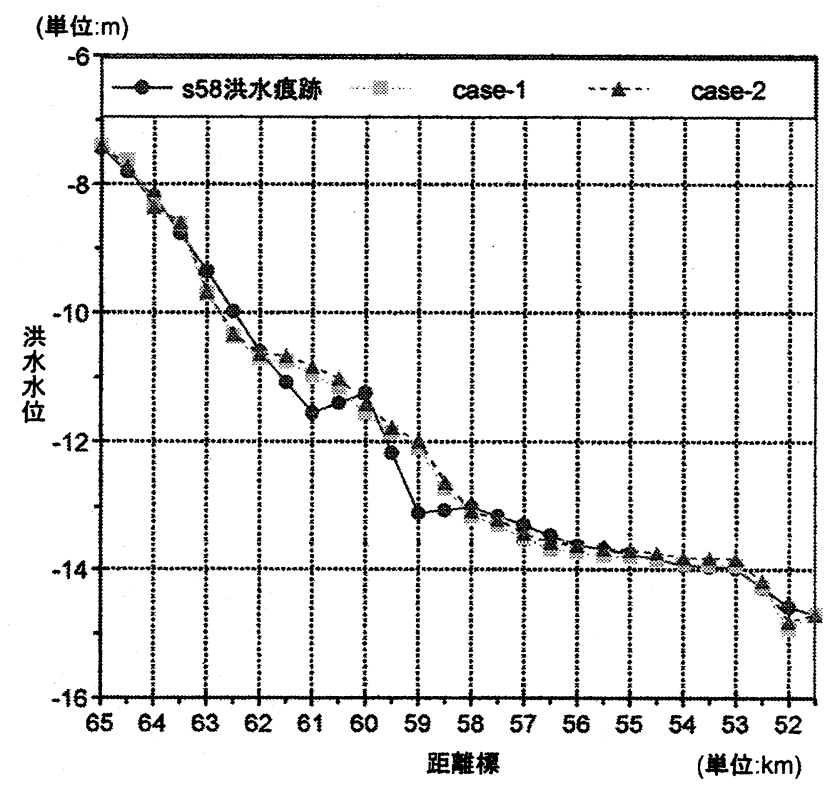

(1) 左岸
にさらに発達すると考えられる粗粒化されたピーク前 の河床材料粒径分布が必要となってくるが, 利用でき る実測值がない，そこで本研究では，最初に 20 区分 全ての粒径の割合を $5 \%$ (平均粒径 $2.831 \mathrm{~cm}$ ) として, そこに $7400 \mathrm{~m}^{3} / \mathrm{s}$ のピーク流量を 24 時間流すことによっ て仮想的な粒径分布を作り出し，その状態から洪水ピ 一ク時の解析をスタートさせるといら手法を取った。

\section{5. 解析結果と考察}

\section{(1)流れの解析結果と考察}

昭和 58 年 9 月に発生した千曲川既往最大洪水 (最 大流量 $7400 \mathrm{~m}^{3} / \mathrm{s}$. 距離標 (県境加) $51.5 \mathrm{~km}$ 地点の最 高水位 $-14.7 \mathrm{~m}$ (海抜 $350 \mathrm{~m}$ を基準)) の解析結果を図一 4, 5に示す.この解析では, 表-1に示す地目別粗度係 数を用いているが, case-1は参考文献8)の標準值を参 考にして, 解析水位が最も良く洪水痕跡線に一致する ように試行錯誤して決めている. case-2の地目別粗度 係数も, case-1と参考文献9)の標準值を参考にして, case-1と同様に決めている.

$C_{u}$ の值の標準值は0.4 0.8であるが,この解析では

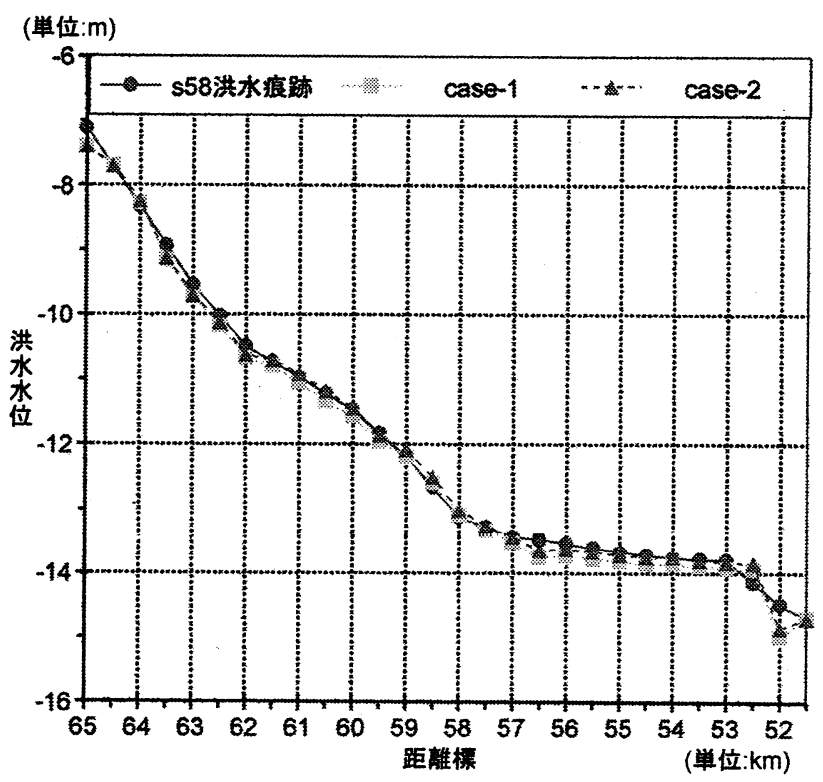

(2) 右岸

図-4 洪水痕跡線と解析水位 (海抜 $350 \mathrm{~m}$ 基準) 
表-1 地目別粗度係数

\begin{tabular}{|c|c|c|c|}
\hline 地目 & 面積割合 & case- 1 & case-2 \\
\hline 果樹 & 0.331 & 0.045 & $*$ \\
\hline 低水路 & 0.220 & 0.030 & 0.030 \\
\hline 砂地 & 0.141 & 0.020 & 0.020 \\
\hline 荒地 & 0.061 & 0.040 & 0.040 \\
\hline 畑 & 0.192 & 0.025 & 0.025 \\
\hline 広葉樹 & 0.046 & 0.060 & $*$ \\
\hline 急縮果樹 & 0.002 & 0.070 & $*$ \\
\hline 桑畑 & 0.007 & 0.050 & 0.050 \\
\hline ここに, *で示す果樹(急縮部果樹を含むp)や広葉
\end{tabular}

樹の地目の粗度係数は, 果樹, 広葉樹ともに $C_{D}$

$: 1.2, C_{u}: 0.2$, 果樹の地目で $n_{b}=0.010$, 広葉樹

の地目で $n_{b}=0.015$ として, 図-2,3の数值を用いて 水位に応じて式(7),(8)で計算する.

0.2 とささ設定している.これは, 解析領域の殆どを占 める果樹は, 日光が満遍なく葉に当たるように毎年伸 びる枝と同量の枝が剪定され樹形が保持され, 自然状 態の樹木に比べ樹冠部が透けていることと, 樹冠部の 投影面積も流れにより縮小しているためである.
図-4の洪水痕跡線と解析水位図では，右岸では洪 水痕跡線にほとんど等しい值が得られたが, 左岸の距 離標61.5〜 59.0km間で差が現れている.これは,この 位置の支川の影響やこの直下流に昭和初期に架設さ れた橋脚間隔の狭い橋があり，橋脚に付いたごみの 影響 (橋脚の抵抗も粗度に換算して考慮している) 等 が考えられる. また, case-1とcase-2を比較するとcase2の方が再現性が高いことがわかる.これは細かな粗 度係数の設定が可能になったためである.

図-5に解析結果の流速分布図を示す. 流れは, 上 流部でcase-2の方が，下流部では若干case-1の方が 速い.これらの相違は粗度係数の違いによるものであ るが, 大洪水であったため多くの樹木は樹冠部まで冠 水状態にあったためか, 全体の流速分布としてはどち らもほとんど等しい結果となっている.

\section{(2)河床変動解析結果と考察}

河床変動結果を図-6〜9に示す. 解析は, case-2 の流速を用いて, 樹木のある地目の掃流力には底面 せん断応力のみが寄与するものとして行った. 図-6 は 4.(3)で述べた方法で求めた河床材料の交換層の粒径

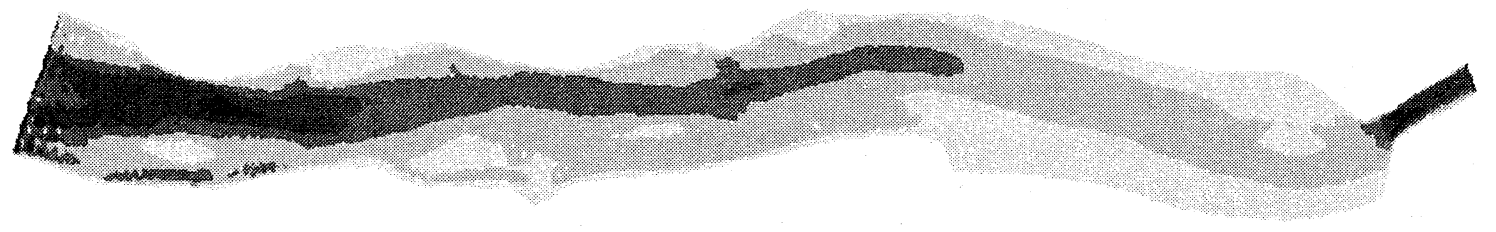

(1) case-1

(2) case-2

図-5 流速分布図

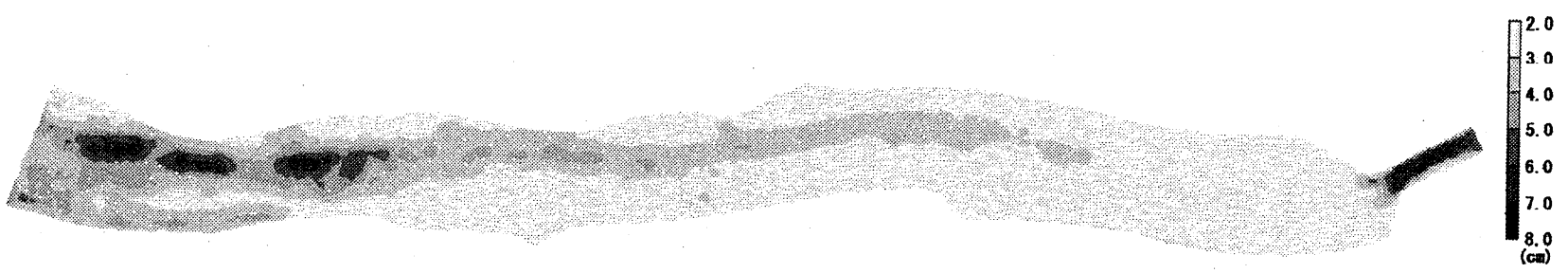

図-6 河床材料の平均粒径の分布の初期值

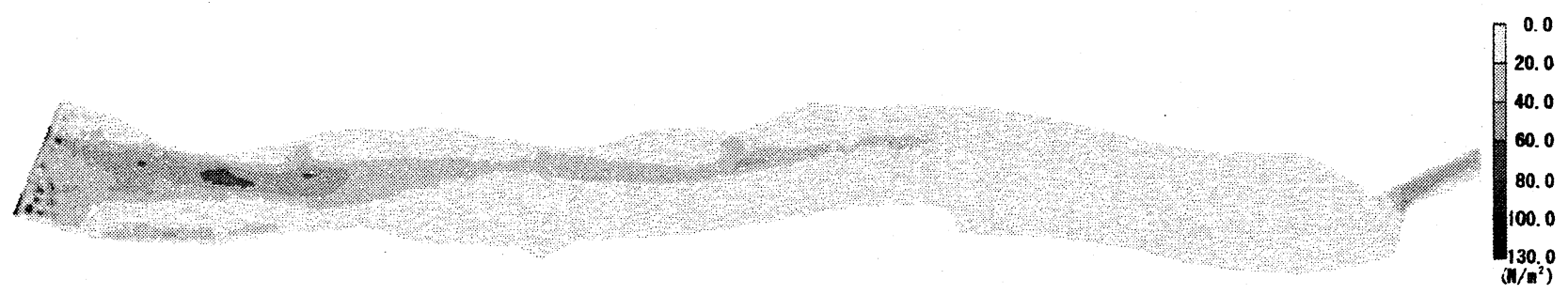

図-7 6 時間経過後の掃流力の分布 
図-8 6時間経過後の初期河床からの河床変動量の分布

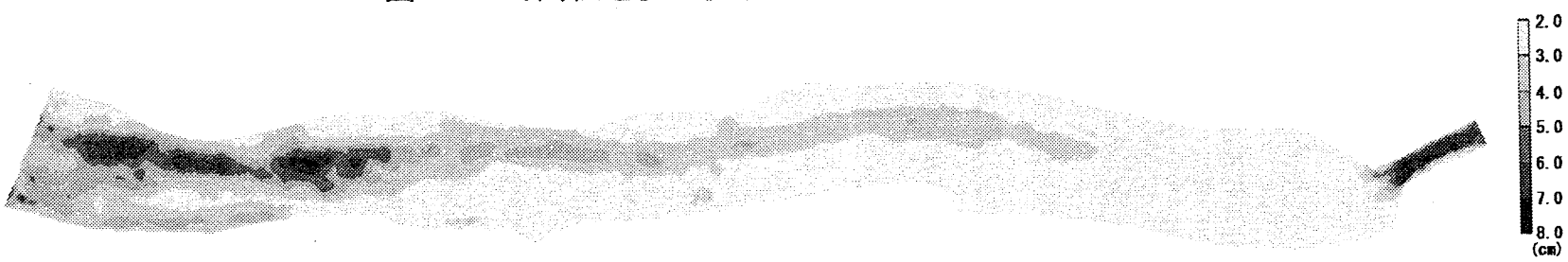

図-9 6時間経過後の河床材料平均粒径の分布

分布の初期值を平均粒径の形で表したものである.さ らに, 図-7，8，9 は, 河床材料は上の粒度分布で, 河 床高は元の地盤に戻し, 洪水ピーク流量が6時間続く ものとして, それぞれ 6 時間経過後の掃流力, 河床変 動量, 河床材料平均粒径の分布を示したものである.

図-6では, 掃流力の大きい上流部の低水路や下流 狭窄部で河床材料の粗粒化のために，4.(3)で述べた 平均粒径 $2.831 \mathrm{~cm}$ より平均粒径が大きくなっているの に対して, 大きく果樹園の拡がっている下流の高水敷 では掃流力が小さいために, 細粒化により平均粒径が 小さくなっている.

図－7の掃流力は, せん断応力が主として流速の二 乗に比例するために, 流速分布に似通った分布にな っている. また, 図-8，9においては, 河床材料の初 期値に粗粒化層が形成された影響で, 河床変動や粗 粒化はそれほど進行していない.しかし，これは河床 材料の初期值が, 中小の洪水等により変化すると, 大 きく変化する可能性がある.

\section{6. 結論}

本研究では, 植生を考慮した千曲川における洪水 流と, この流れによる河床変動の数值解析を行い, 実 在の河川に対する数值解析の予測精度と植生の洪水 流や河床変動に及ぼす影響について検討したもの で, 得られた結論を以下に述べる.

・解析の難しい広範囲に植生の存在する急縮部を含 む実河川の洪水流を解析できた。

-千曲川の58年当時の地目別粗度係数を決定するこ とができた。

・水深によって粗度係数を変化さて, 昭和 58 年洪水を 高精度で再現することができた。

・粗粒化現象を含む河床変動の大まかな予測が可能 な解析方法を作成できた.

今後は, 本研究の解析方法により, 植生分布の変
化している現在の千曲川の洪水に対する安全性を評 価することと, 河床変動解析では, 河床変動の実測値 のある河道を解析対象としたり，水理模型実験結果と の比較などを通して, 解析精度を確かめる必要があ る. また, 洪水の発生から収束までという一連の流れや 河床変動の再現を目指すことも必要である.

最後に, 貴重なデータを提供して下さいました, 建 設省千曲川工事事務所の関係者に感謝を表する次 第です.

\section{参考文献}

1）富所五郎:有限要素法による水理解析, 1991年度 (第27回) 水工学に関する夏期研修会講義集, pp.A $-1-1 \sim A-1-17,1991$.

2）例えば 椿東一郎: 水理学 II, 森北出版, pp.188, 1979.

3) 水理公式集:河川編, 土木学会編, pp.201 203, 1971.

4）西本直史, 清水康行, 青木敬三:流線の曲率を考 慮した蛇行水路の河床変動計算, 土木学会論文 集, No.456，II -21，pp.11 20，1992.

5）リバーフロント整備センター:千曲川平成 11 年度 洪水の河岸被災原因と復旧手法評価検討委員会 第1回検討委員会資料, 平成 11 年度千曲川多自 然型川づくり検討業務報告書, pp.3 22，2000.

6）建設省河川局治水課: 河道内の樹木の伐採・植樹 ためのガイドライン, 山海堂, pp.70 72, 1994.

7) 松本良一, 富所五郎:FEM流れ解析におけるAMR (Adaptive Mesh Refinement)の適用について, 水工 論文集, pp.1071 1076, 1996.

8) Ven Te Chow:開水路の水理学 I, 石原藤治郎 訳, 丸善出版, pp.92 111, 1954 .

4) 6)に同じ, pp.29 33, 1994. 